\title{
Heavy Metals in Soils from High Andean Zones and Potential Ecological Risk Assessment in Peru's Central Andes
}

\author{
Edith Orellana Mendoza1*, María Custodio', Julio Ascensión', María Carolina Bastos² \\ 1 Universidad Nacional del Centro del Perú, Av. Mariscal Castilla 3909-4089, El Tambo Huancayo, Perú \\ 2 Centro Internacional de la Papa - CIP, Huancayo \\ * Corresponding author's e-mail: eporellana@uncp.edu.pe
}

\begin{abstract}
Soil is exposed to heavy metals that are associated with the anthropogenic activities, and is currently an environmental and food safety problem. The concentration and source of heavy metals in soils, the level of contamination and the potential for ecological risk in high Andean ecosystems were evaluated. The soil samples were collected from the surface part in which Andean crops were sown and the concentration of $\mathrm{As}, \mathrm{Cd}, \mathrm{Pb}, \mathrm{Fe}$ and $\mathrm{Zn}$ was quantified. The concentrations of heavy metals in soils did not exceed the threshold of the national and international standard, while $\mathrm{As}, \mathrm{Pb}$ and $\mathrm{Zn}$ exceeded the values of the background. The contamination factor $(\mathrm{CF})$ values showed a high level of contamination for As and moderate for $\mathrm{Pb}$ and $\mathrm{Zn}$. The geoaccumulation index (Igeo) values showed that As had the highest load of accumulated pollutants in soils by anthropogenic contribution. A moderate degree of contamination (CD) was found in $61.5 \%$ of the sampling sites. The potential ecological risk index (RI) showed that the soils of the study area presented a moderate to low potential ecological risk, and As was the main pollutant in high Andean soils. As, $\mathrm{Pb}$ and $\mathrm{Zn}$ occurring in high Andean soils mainly originated from human activities such as agricultural practices, whereas Fe mainly originated from the parent material of the soil. The effects of the use of organic and inorganic fertilizers on the accumulation of heavy metals in and Andean agricultural products must be analyzed and verified to protect the health of the inhabitants and the environment.
\end{abstract}

Keywords: heavy metals, agricultural soils, high Andean areas, pollution index, ecological risk.

\section{INTRODUCTION}

Soil is an important component of the biosphere, a fundamental sustenance for food crops (Kumar et al. 2019, Rai et al. 2019), sink of nutrients and pollutants (Wu et al. 2018). In general, the heavy metals in soil come from the natural sources associated with the parent material or from the anthropogenic sources (Jiang et al., 2019), Naturally, they are found in very low concentrations, while high concentrations are commonly associated with the pollutants resulting from human activities (Chandrasekaran and Ravisankar 2019, Islam et al. 2017). Mining, smelting processes, solid waste, fossil fuels, urban and industrial wastewater irrigation, agricultural activities are the most important sources of heavy metals caused by human activities
(Alloway 2013, Davies 1987, Huang et al. 2007, I. ur Rehman et al. 2018, Yang et al. 2018). The soil contamination due to the prolonged use of pesticides and chemical fertilizers is another source that has been causing the accumulation of metals and deterioration of agricultural soils (Liu et al. 2019).

Heavy metals are one of the most dangerous pollutants in our natural environment due to their toxicity, persistence and bioaccumulation. They are considered dangerous for human health and the ecosystem (Enuneku et al. 2017, U. ur Rehman et al. 2018). Currently, these pollutants are causing adverse effects on the crop quality, posing a threat to food security and human health (Li et al. 2018). Overall, the quality and productivity of soils from different land uses is deteriorating worldwide due to various anthropogenic 
activities (Bhatti, Kumar et al. 2018). The use of fertilizers and pesticides leads to an increase in the productivity of crops, but the excessive and prolonged use of these chemical substances can cause changes in the structure and function of the soil and the generation of contaminants $(\mathrm{Cu}, \mathrm{Zn}$, $\mathrm{Cd}, \mathrm{Pb}, \mathrm{Cr}, \mathrm{Ni}, \mathrm{Hg}$ and $\mathrm{As}$ ) on a large scale for the environment (Chen et al. 2015, Liang at al. 2015). Therefore, it is very important to assess the distribution and sources of heavy metals in agricultural soils in order to protect the ecological environment and human health.

Ecological risk assessment is a tool that allows evaluating the impact of chemical pollutants on ecosystems (Huang et al. 2019), used by researchers to assess the state of the soil environment due to the long-term accumulation of heavy metals (Mirzaei et al. 2019, Weissmannová and Pavlovský 2017). Several authors studied the heavy metal contamination of agricultural soils and ecological risk, in different countries, such as China, India, Iran, Poland, and Nigeria (Baran et al. 2018, Bhatti, Bhat et al. 2018, Chandrasekaran and Ravisankar 2019, Enuneku et al. 2017, Huang et al. 2019, Shen et al. 2019, Wu et al. 2018, Xiao et al. 2019, Zhu et al. 2018). The studies on soil pollution and ecological risk from heavy metals, particularly in high Andean ecosystems remain limited.

In Peru, mining activity and mining environmental liabilities (effluents, emissions, waste produced by abandoned and inactive mining operations) are sources of the contamination of aquatic ecosystems, soils, air, vegetation and a permanent and potential risk to ecosystems, such as La Oroya (Chang Kee et al. 2018, Loayza-Muro 2016). On the other hand, agricultural practices are sources of the heavy metal contamination associated with the use of fertilizers and agrochemicals, the farmers in the Junín region use these products to improve the production of their Andean agricultural products such as native potato (Solanum tuberosum), olluco (Ullucus tuberosus), mashua (Tropaeolum tuberosum) and oca (Oxalis tuberosa), and these products constitute the basic food of the Andean population, due to their nutritional value as food and usefulness as natural medicine (Del Aguila Lopez 2018). Therefore, it is a concern to assess the level of soil contamination, because it affects not only the growth and yield of crops but also the food security of local residents. The objectives of the research were (1) to determine the concentration, sources and levels of the heavy metal contamination $(\mathrm{Cd}, \mathrm{Pb}, \mathrm{Fe}, \mathrm{Zn}$ and $\mathrm{As})$ in the high Andean soils for agricultural use and (2) to evaluate the potential ecological risk for heavy metals in the superficial soils from the central highlands, Junín.

\section{MATERIALS AND METHODS}

\section{Study area}

The scope of the study includes the high Andean areas of the provinces of Huancayo, Concepción, Jauja and Chupaca in the department of Junín (Figure 1), on the left bank of the Mantaro Valley between the altitudes of $3700 \mathrm{~m}$ a.s.l. to 4200 masl. They present a cold sub-humid mountain climate, with an annual average temperature of $8.5^{\circ} \mathrm{C}$, a maximum temperature of $18.2^{\circ} \mathrm{C}$ and a minimum temperature of $-10.3^{\circ} \mathrm{C}$, with a mean rainfall of $630 \mathrm{~mm}$, ranging between 580 and $721 \mathrm{~mm}$ annually. The physiography of the terrain is mountainous with steep slopes. The soils belong to the group of entisols and inceptisols, originating from sedimentary material, good and moderate drainage, moderate permeability, superficial to moderately deep soils, medium to moderately textured thick, with $\mathrm{pH}$ of 5.1-6.4. The main economic activity of the Andean settlers is livestock and subsistence agriculture, the planting of their Andean products (native potato, olluco, mashua and oca) is carried out in the rainy season between September and October in small plots of $700 \mathrm{~m}^{2}$ to $1250 \mathrm{~m}^{2}$.

\section{Sample collection and analysis}

In August 2019, the agricultural plots where Andean products were grown were selected, six to eight plots were chosen for each locality. In each selected plot, five soil samples were collected, which were mixed and homogenized in a plastic container, to obtain a composite soil sample of $1 \mathrm{~kg}$ each, at a depth of $0-20 \mathrm{~cm}$ below ground level (Kicińska 2020). The soil samples were placed in self-closing polyethylene bags by means of a stainless steel spatula and transported to the laboratory. The location of the sampling sites was recorded using a portable global positioning system (GPS). The samples were air dried at room temperature for eight days and sieved through a $2 \mathrm{~mm}$ mesh to remove thick remains. 


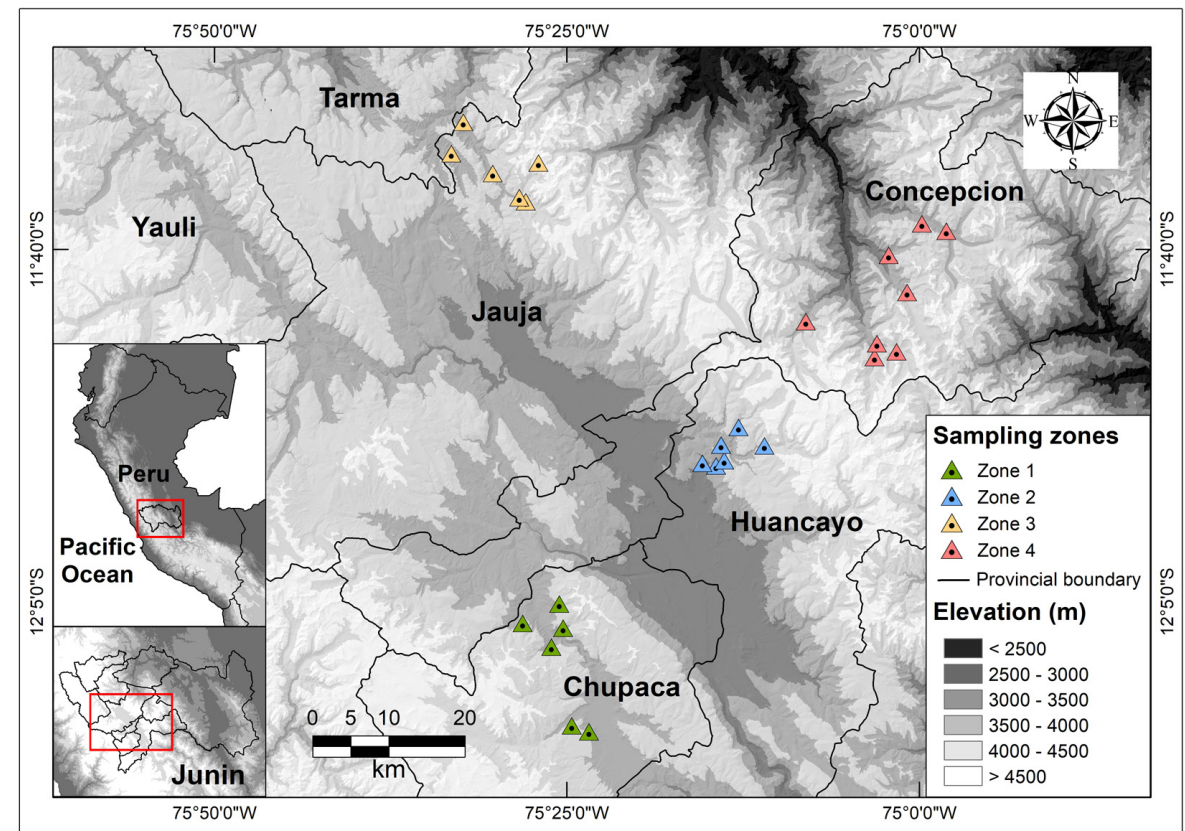

Figure 1. Location map of the soils sampling sites in the high Andean zones of Junín, Peru

In the laboratory, $10 \mathrm{~g}$ of soil sample was pulverized using a pulverizing mill with a zirconia oxide grinding system, and then sieved through a 100 mesh nylon sieve. The samples were analyzed following the 3051A (USEPA 2007) method, approximately $0.5 \mathrm{~g}$ of soil sample was weighed in a beaker, $9 \mathrm{ml}$ hydrochloric acid $(\mathrm{HCl})$ and $3 \mathrm{ml}$ of nitric acid $\left(\mathrm{HNO}_{3}\right)$ were added in a 3:1 ratio then, they were sealed and subjected to temperatures of $180^{\circ} \mathrm{C}$ until they acquired a pasty density. The digested samples were diluted with ultrapure water and poured into $100 \mathrm{ml}$ flasks, filtered with $200 \mathrm{~mm} \emptyset$ No. 42 filter paper, finally the samples were stored at $4^{\circ} \mathrm{C}$ until the later analysis. The determination of heavy metals and arsenic was performed with the flame atomic absorption spectrophotometry method (air-acetylene) using the atomic absorption spectrometer (Varian model AA240FS). Standard solutions of the five metals studied were used to establish the calibration curves; then, the respective samples were read. The recoveries of heavy metals ranged from $80 \%$ to $120 \%$.

\section{Assessment of soil contamination for heavy metals}

\section{Contamination factor (CF)}

The CF was used to measure the relationship between the content of each heavy metal in the soil with respect to the geochemical background value (concentration in uncontaminated soil), it is an indicator of contamination by anthropogenic contributions associated with a single heavy metal (Hakanson 1980), the equation (1) was as follows:

$$
\mathrm{CF}=\mathrm{C}_{\text {soil }} / \mathrm{C}_{\text {background }}
$$

where: $C_{\text {soil }}$ is the concentration of each metal in the soil samples, and

$C_{\text {background }}$ is the background value of each metal that indicates the concentration of the metal in the soil when there was no anthropogenic input. In Peru, there are no studies on the background values of metals in soils, so the background values reported by Taylor and Mclennan (1995) were used for $\mathrm{As}, \mathrm{Cd}, \mathrm{Fe}, \mathrm{Pb}$ and $\mathrm{Zn}$ with $1.5,1.0,35000,20$ and $71 \mathrm{mg} / \mathrm{kg}$ respectively, and Bhatti et al. (2018) used these values. Hakanson (1980) categorized the contamination values as follows: low contamination $(\mathrm{CF}<1)$, moderate contamination $(1<\mathrm{CF}<3)$, considerable contamination $(3<\mathrm{CF}<6)$ and very high contamination $(\mathrm{CF}>6)$.

\section{Pollution load index (PLI)}

The PLI provides a simple and comparative means of assessing the soil quality through the level of soil contamination by heavy metals. PLI 
is defined as the $n$-th root of the multiplications of the contamination factor for each metal, and is calculated according to equation (2):

$$
\mathrm{PLI}=(\mathrm{CF} 1 \times \mathrm{CF} 2 \times \mathrm{CF} 3 \times \cdots \times \mathrm{CFn})^{1 / n}
$$

where: $C F$ is the pollution factor and $\mathrm{n}$ is the number of heavy metals considered. Two classes of PLI were proposed by Tomlinson (Tomlinson et al. 1980), when PLI> 1 , it means that there is contamination, if PLI $<1$ there is no contamination for metals.

\section{Geoaccumulation index (Igeo)}

The geoaccumulation index (Igeo) quantifies the degree of pollutants load accumulated by the anthropogenic or geogenic contributions in soil and it was determined using equation (3) suggested by Muller (Muller 1969):

$$
\text { Igeo }=\log _{2}(\mathrm{Cn} / 1.5 \mathrm{Bn})
$$

where: $\mathrm{Cn}$ is the heavy metal content in the soil sample $\mathrm{n}$ and $\mathrm{Bn}$ is the geochemical background value of the metal $\mathrm{n}$ in the corresponding soil. Constant 1.5 is the correction factor due to the lithogenic effects and natural fluctuations of metals in the environment (Kamani et al. 2017). The geoaccumulation index (Igeo) was classified into seven classes (Muller 1979): uncontaminated (Igeo $\leq 0$ ), uncontaminated to moderately contaminated $(0<$ Igeo $\leq 1)$, moderately contaminated $(1<$ Igeo $\leq 2)$, moderately to highly contaminated $(2<$ Igeo $\leq 3)$, highly contaminated $(3<$ Igeo $\leq 4)$, highly contaminated to extremely contaminated $(4<\operatorname{Igeo} \leq 5)$ and extremely contaminated (Igeo $>5$ ).

\section{Contamination degree $(C D)$}

The CD is a diagnostic tool that was developed by Hakanson to simplify the contamination control study. The sum of the contamination factor (CFi) for all metals represents the contamination degree (CD), which is expressed in equation (4):

$$
\mathrm{CD}=\sum_{i=1}^{n} \mathrm{CFi}
$$

where: $C F i$ is the contamination factor for each metal $i$. The degree of pollution was classified into four classes: low degree of pollution $(\mathrm{CD}<8)$, moderate degree of pollution $(8 \leq \mathrm{CD}<16)$, considerable degree of pollution $(16 \leq \mathrm{CD}<32)$ and high degree of pollution $(\mathrm{CD}>32)$.

\section{Assessment of potential ecological risk for heavy metals in soils}

The toxicity and potential ecological risks of heavy metals in the soil were evaluated using the method proposed by Hakanson (1980):

\section{Potential ecological risk index (RI)}

RI was calculated to assess the damaging effect of all heavy metals on the soils studied through the equations (5) and (6):

$$
\begin{gathered}
\mathrm{RI}=\sum_{i=1}^{n} E R I i \\
\overline{E R} \hat{I} i=\sum_{i=1}^{n} \operatorname{Tr} i x C F i
\end{gathered}
$$

where: ERIi is the potential ecological risk index of an individual metal $i$, Tri represents the toxic response factor of metal $\mathrm{i}$, and $\mathrm{CFi}$ is the contamination factor of metal $\mathrm{i}$. The toxicological response factor for $\mathrm{As}, \mathrm{Cd}$, $\mathrm{Pb}, \mathrm{Fe}$ and $\mathrm{Zn}$ was considered 10, 30, 5, 1 and 1, respectively (Li et al. 2020, Mirzaei et al. 2018). The potential ecological risk factor associated with an individual metal (ERI) was classified as: low risk $($ ERI $<40)$, moderate risk $(40 \leq \mathrm{ERI}<80)$, considerable risk $(80 \leq \mathrm{ERI}<160)$, high risk $(160 \leq \mathrm{ERI}<320)$ and very high risk $(E R I \geq 320)$. Potential ecological risk index (RI) was categorized as follows: low risk (RI $<95)$, moderate risk $(95 \leq \mathrm{RI}<190)$, high risk $(190 \leq \mathrm{RI}<380)$, very high risk ( $\mathrm{RI}>380)$ (Essien et al. 2019, Wu et al. 2015).

\section{Data analysis}

The data collected were processed using the statistical software SPSS (v23), which were systematized in tables and figures. The statistic used was one-way ANOVA and the Tukey test to measure the differences in heavy metals between the study areas at a significance level of 0.05 . Pearson's correlation and principal component analysis (PCA) were used to identify the possible sources of contamination by heavy metals in the soils from the high Andean areas. 


\section{RESULTS AND DISCUSSION}

\section{Heavy metal concentration in the high Andean soils}

The descriptive statistics of concentration of heavy metals in the high Andean soils where the Andean agricultural products are grown, these are presented in Table 1. The mean values of heavy metals concentration in soils showed a trend: $\mathrm{Fe}>\mathrm{Zn}>\mathrm{Pb}>\mathrm{As}>\mathrm{Cd}$ with averages of 24360.03 , $79.18,28.31,9.41$ and $0.27 \mathrm{mg} / \mathrm{kg}$ respectively. The content of these metals in soils was found below the national and international environmental quality standards. In all soil samples, the content of Fe was highest, while the content of Cd registered the lowest value. These results were consistent with the metals found in agricultural soils in India (Kumar et al. 2019). Significant differences were detected in the concentrations of $\mathrm{As}, \mathrm{Cd}, \mathrm{Pb}$ and $\mathrm{Zn}$ between the different study areas $(\mathrm{p}<0.05)$, the soils of zone 2 in Huancayo registered a higher concentration of these metals followed for zone 3 in Jauja, which could indicate variations in the impact of the anthropogenic activities in the high Andean zones. However, the average content of $\mathrm{As}, \mathrm{Pb}$ and $\mathrm{Zn}$ exceeded the background value on 6.2, 1.4 and 1.1 times respectively, which could indicate that the soils in the study area were contaminated by the anthropogenic activities (Wu et al. 2018, Xiao et al. 2019). The concentrations of
$\mathrm{Cd}$ and Fe did not exceed the natural background values, which could reveal that the soils were not contaminated with these metals.

The coefficient of variation (CV) indicates the degree of variability of the concentrations of a metal in soil. A low CV value indicates that the heavy metal contamination of soils is due to the natural sources and a high $\mathrm{CV}$ value indicates that it is caused mainly by the human activities (Cai et al. 2015, Mamut et al. 2018). The maximum $\mathrm{CV}$ was recorded for $\mathrm{Pb}(60.72 \%)$ and $\mathrm{As}$ $(51.43 \%)$, which could involve a high variability of these two metals in the sampling sites, it means that the distribution of these chemical elements in the studied area was not homogeneous in comparison to $\mathrm{Zn}, \mathrm{Cd}$ and $\mathrm{Fe}$ that showed moderate variability.

\section{High Andean soils contamination for heavy metals}

The calculated values of the contamination factor (CF), contamination degree (CD) and the pollution load index (PLI) for heavy metals in soils are presented in Table 2 . The average CF values of heavy metals were found in the following order: $\quad \operatorname{As}(6.22)>\mathrm{Pb}(1.29)>\mathrm{Zn}(1.08)>\mathrm{Fe}(0.70)>$ $\mathrm{Cd}(0.28)$. The average $\mathrm{CF}$ value for As showed a very high contamination level $(\mathrm{CF}>6)$, while the average $\mathrm{CF}$ values for $\mathrm{Pb}$ and $\mathrm{Zn}$ indicated a moderate contamination level $(1<\mathrm{CF}<3)$, and

Table 1. Mean $( \pm \mathrm{SD})$ of concentration of heavy metals and arsenic $(\mathrm{mg} / \mathrm{kg})$ in the soils collected from the high Andean zones of Junín

\begin{tabular}{|c|c|c|c|c|c|c|}
\hline Sampling sites & Descriptive statistics & As & $\mathrm{Cd}$ & $\mathrm{Pb}$ & $\mathrm{Fe}$ & $\mathrm{Zn}$ \\
\hline \multirow{2}{*}{ Zone 1} & Mean & $8.762^{a}$ & $0.288^{b}$ & $29.66^{b}$ & $21,099.47^{a}$ & $76.02^{a b}$ \\
\hline & SD & 2.473 & 0.054 & 8.27 & $6,887.83$ & 11.34 \\
\hline \multirow{2}{*}{ Zone 2} & Mean & $14.816^{b}$ & $0.336^{b}$ & $45.70^{c}$ & $28,893 \cdot 17^{a}$ & $96.90^{b}$ \\
\hline & SD & 3.199 & 0.041 & 15.26 & $5,944.69$ & 18.67 \\
\hline \multirow{2}{*}{ Zone 3} & Mean & $11.598^{b}$ & $0.260^{\mathrm{b}}$ & $35.97^{b c}$ & $23,257.33^{a}$ & $89.38^{a b}$ \\
\hline & SD & 3.584 & 0.079 & 10.04 & $7,292.95$ & 20.01 \\
\hline \multirow{9}{*}{ Zone 4} & Mean & $4.203^{a}$ & $0.215^{a}$ & $8.51^{a}$ & $24,232.63^{a}$ & $60.60^{a}$ \\
\hline & SD & 1.517 & 0.070 & 2.96 & $4,897.85$ & 19.05 \\
\hline & General mean & 9.411 & 0.270 & 28.31 & $24,360.03$ & 79.18 \\
\hline & SD & 4.840 & 0.075 & 17.19 & $6,456.86$ & 22.15 \\
\hline & Minimum & 2.338 & 0.123 & 4.67 & $13,684.00$ & 36.55 \\
\hline & Maximum & 19.986 & 0.402 & 67.82 & $38,789.25$ & 124.18 \\
\hline & CV $(\%)$ & 51.43 & 27.77 & 60.72 & 26.51 & 27.97 \\
\hline & MAL & $50^{a}$ & $14^{a}$ & $70^{a}$ & - & $300^{\mathrm{b}}$ \\
\hline & 'Background value & 1.5 & 1.0 & 20 & 35000 & 71 \\
\hline
\end{tabular}

SD (standard deviation). CV (coefficient of variation). MAL (Maximum allowable limits) according a(Ministerio del Ambiente (MINAM), 2017) and ${ }^{\mathrm{b} E n v i r o n m e n t a l}$ Quality Standard for Soils (CEPA, 1995). ${ }^{\mathrm{C} B a c k g r o u n d}$ value (Taylor \& Mclennan, 1995) 
Table 2. Contamination factor (CF), pollution loading index (PLI) and contamination degree (CD) of heavy metals and arsenic in soils collected from high Andean zones of Junín

\begin{tabular}{|c|c|c|c|c|c|c|c|}
\hline \multirow{2}{*}{ Sampling sites } & \multicolumn{5}{|c|}{ Contamination Factor (CF) } & \multirow{2}{*}{ CD } & \multirow{2}{*}{ PLI } \\
\hline & As & $\mathrm{Cd}$ & $\mathrm{Pb}$ & $\mathrm{Fe}$ & $\mathrm{Zn}$ & & \\
\hline Zone 1 & $5.619^{b}$ & $0.322^{\mathrm{a}}$ & $1.483^{a}$ & $0.603^{a}$ & $1.071^{\mathrm{ab}}$ & $9.097^{b}$ & $1.101^{b}$ \\
\hline Zone 2 & $9.877^{a}$ & $0.319^{a}$ & $2.118^{a}$ & $0.826^{a}$ & $1.365^{\mathrm{a}}$ & $14.505^{\mathrm{a}}$ & $1.475^{\mathrm{a}}$ \\
\hline Zone 3 & $7.732^{\mathrm{ab}}$ & $0.293^{\mathrm{ab}}$ & $1.465^{a}$ & $0.664^{a}$ & $1.118^{a b}$ & $11.273^{b}$ & $1.158^{b}$ \\
\hline Zone 4 & $2.802^{c}$ & $0.215^{\mathrm{b}}$ & $0.394^{b}$ & $0.692^{\mathrm{a}}$ & $0.853^{\mathrm{b}}$ & $4.957^{c}$ & $0.658^{c}$ \\
\hline General mean & 6.222 & 0.282 & 1.290 & 0.696 & 1.083 & 9.573 & 1.055 \\
\hline SD & 3.209 & 0.070 & 0.774 & 0.184 & 0.302 & 4.070 & 0.339 \\
\hline Minimum & 1.559 & 0.123 & 0.234 & 0.391 & 0.515 & 3.414 & 0.496 \\
\hline
\end{tabular}

the average $\mathrm{CF}$ values for $\mathrm{Fe}$ and $\mathrm{Cd}$ indicated a low contamination level $(\mathrm{CF}<1) .50 \%, 61.5 \%$ and $61.5 \%$ of the sampled sites were contaminated with $\mathrm{As}, \mathrm{Pb}$ and $\mathrm{Zn}$ respectively, these results suggest that those metals have accumulated on the soil surface over time, and mostly correspond to zones 1 and 2. The contamination degree (CD) of heavy metals in soils was moderate and low (Table 2). $61.5 \%$ of the sampling sites presented a moderate contamination degree $(8 \leq \mathrm{CD}<16)$, while $38.5 \%$ presented a low contamination degree $(\mathrm{CD}<8)$. $\mathrm{As}, \mathrm{Pb}$ and $\mathrm{Zn}$ were the elements that contributed to the degree of contamination of high Andean soils in zones 1,2 and 3. The average value of the pollution load index (PLI) was 1.06, slightly higher than 1 ; therefore, it was detected that the soils of the studied area presented light contamination by heavy metals. In the four zones, the PLI average followed in decreasing order: zone $2(1.48)>$ zone $3(1.16)>$ zone $1(1.10)>$ zone 4(0.66). Zone 4 in Concepción registered lower levels of pollution degree with a PLI less than 1.

\section{Geoaccumulation index (Igeo)}

The Igeo values of heavy metals varied significantly in the different sites and are presented in Figure 2. The average Igeo values decreased in the following order: As $(1.84 \pm 0.84)>\mathrm{Zn}$ $(-0.53 \pm 0.44)>\mathrm{Pb}(-0.56 \pm 1.10)>\mathrm{Fe}(-1.16 \pm 0.39)>$ $\mathrm{Cd}(-2.47 \pm 0.41)$, the minimum and maximum values of Igeo were from -3.61 (Cd) to 3.15 (As), which could indicate that As showed a higher load of pollutants accumulated in soils by the anthropogenic input in the four studied areas. The ranges in the Igeo values for each individual element were not very wide, demonstrating little variability in the soil properties and the sources of contamination of the soil by heavy metals. Furthermore, the mean Igeo values for $\mathrm{As}$ and $\mathrm{Pb}$ in the four zones were positive, while $\mathrm{Cd}, \mathrm{Fe}$ and
Zn showed mostly negative Igeo values. More than $81 \%$ of the soil samples were contaminated with As from moderate level $(1<$ Igeo $\leq 2)$ to moderately to highly contaminated level $(2<$ Igeo $\leq$ $3) ; 42 \%$ of the sampling sites were contaminated with $\mathrm{Pb}$ at the level of uncontaminated to moderately contaminated $(0<$ Igeo $\leq 1) . \mathrm{Cd}, \mathrm{Fe}$ and $\mathrm{Zn}$ did not present load of pollutants in the soil (Igeo $\leq 0$ ), which could indicate that the sampling sites in the four locations were not contaminated with these three elements. As caused a more serious contamination than the other elements based on the geoaccumulation index, which could be attributed to the anthropic activities such as agricultural practices (Kabata-Pendias 2011, KabataPendias and Mukherjee 2007). Significant differences were detected between the study areas, zones 2 (Huancayo) and 3 (Jauja) showed higher Igeo values by As higher than 2, classifying them from moderately to highly contaminated for As; soils in the study area were not contaminated by $\mathrm{Cd}, \mathrm{Fe}$ and $\mathrm{Zn}$.

\section{Potential ecological risk index (RI)}

The potential ecological risk index (ERI) values of each heavy metal and As decreased in the following order As $(62.22 \pm 32.09)>\mathrm{Cd}$ $(8.45 \pm 2.11)>\mathrm{Pb}(6.45 \pm 3.87)>\mathrm{Zn}(1.08 \pm 0.30)>$ $\mathrm{Fe}(0.69 \pm 0.18)$ (Table 3, Figure 3). The average ERI value for As $(40 \leq E R I<80)$ suggested that it could present a moderate potential ecological risk, while the ERI values for $\mathrm{Cd}, \mathrm{Pb}, \mathrm{Zn}$ and Fe were lower than ERI $<40$ which suggested a low potential ecological risk for these four metals in the four study areas. It was observed that $27 \%$ of the sampled sites in the four zones presented a considerable potential ecological risk for As $(80 \leq \mathrm{ERI}<160), 38 \%$ of moderate level $(40 \leq \mathrm{ERI}<80)$ and $35 \%$ of low level $(\mathrm{ERI}<40)$. Zone 2 (Huancayo) presented a considerable 
a)

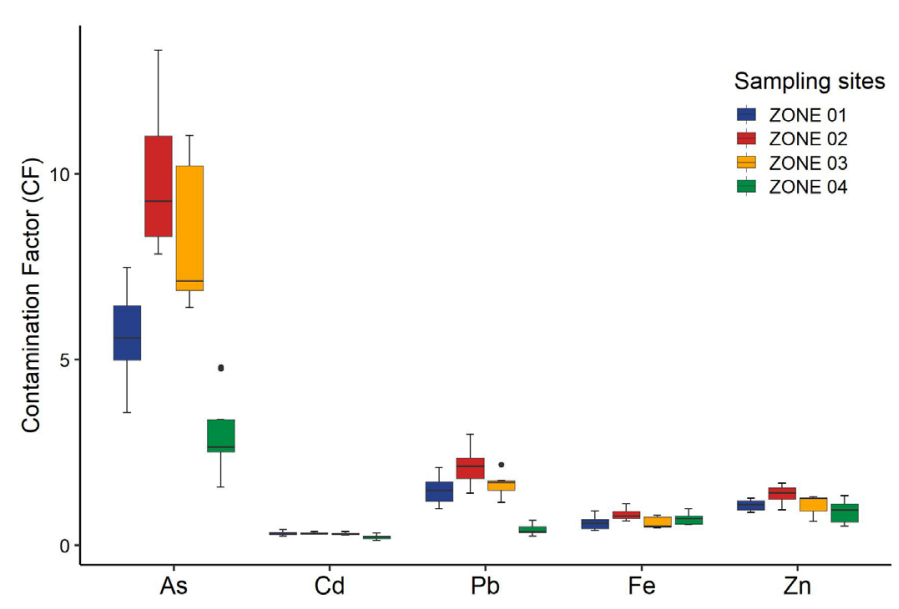

b)

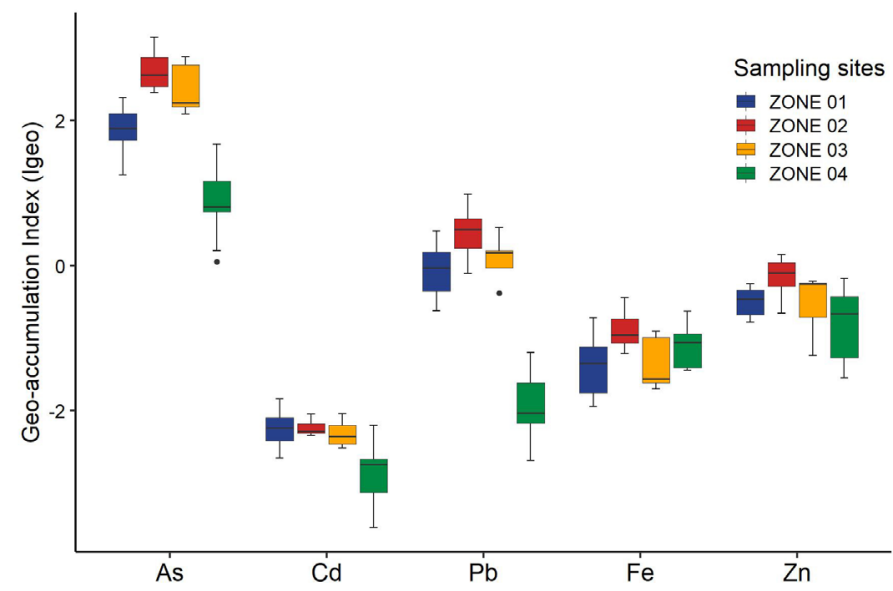

Figure 2. Contamination factor (CF) and geo-accumulation index (Igeo) of heavy metals and arsenic in soils collected from high Andean zones of Junín

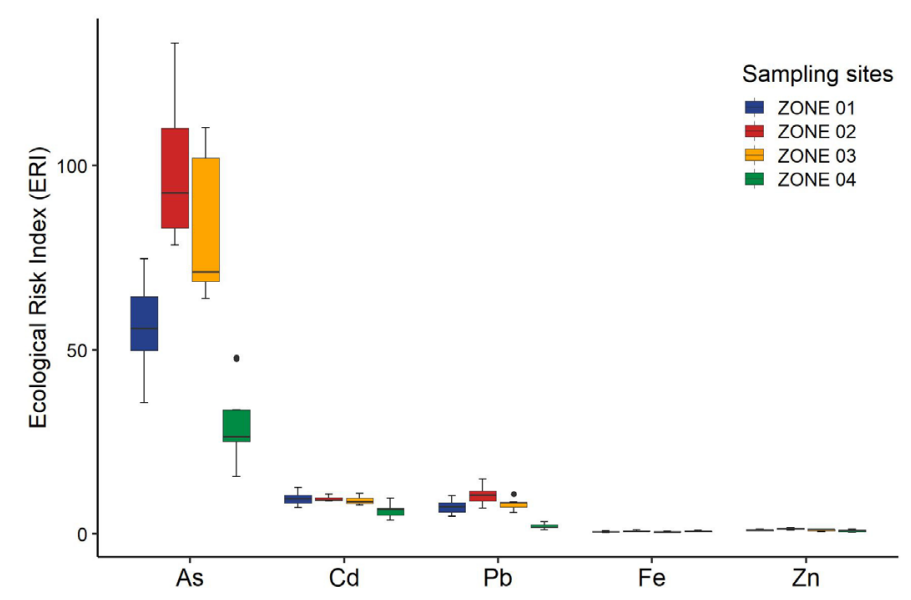

Figure 3. Potential ecological risk index of individual metals (ERI) and arsenic in soils of high Andean zones of Junín

ecological risk level for As and zones 1 (Chupaca) and 3 (Jauja) presented a moderate ecological risk level for As. The levels of the total potential ecological risk (RI) showed significant differences between the studied areas, and the averages followed the decreasing order: zone 2 $(121.13 \pm 20.71)>$ zone $3(95.22 \pm 25.79)>$ zone $1(74.92 \pm 16.00)>$ zone $4(37.99 \pm 11.52)$ which could indicate a moderate to low risk for the heavy metals and arsenic. $65.4 \%$ of the total 
Table 3. Potential ecological risk index of individual metals (ERI) and potential ecological risk index (RI) of heavy metals and arsenic in soils collected from high Andean zones of Junín

\begin{tabular}{|c|c|c|c|c|c|c|c|c|}
\hline \multirow{2}{*}{$\begin{array}{c}\text { Sampling } \\
\text { points }\end{array}$} & \multirow{2}{*}{$\begin{array}{l}\text { Descriptive } \\
\text { statistics }\end{array}$} & \multicolumn{5}{|c|}{ Potential ecological risk index (ERI) } & \multirow{2}{*}{ RI } & \multirow{2}{*}{ Level of RI } \\
\hline & & As & $\mathrm{Cd}$ & $\mathrm{Pb}$ & $\mathrm{Fe}$ & $\mathrm{Zn}$ & & \\
\hline \multirow{2}{*}{ Zone 1} & Mean & 56.188 & 9.645 & 7.414 & 0.603 & 1.071 & 74.920 & Low risk \\
\hline & SD & 13.731 & 1.938 & 2.068 & 0.197 & 0.160 & 16.007 & \\
\hline \multirow{2}{*}{ Zone 2} & Mean & 98.773 & 9.575 & 10.591 & 0.826 & 1.365 & 121.130 & Moderate risk \\
\hline & SD & 21.330 & 0.771 & 2.768 & 0.170 & 0.263 & 20.711 & \\
\hline \multirow{2}{*}{ Zone 3} & Mean & 77.320 & 8.790 & 7.326 & 0.664 & 1.118 & 95.219 & Low risk \\
\hline & SD & 23.894 & 1.393 & 2.757 & 0.208 & 0.279 & 25.792 & \\
\hline \multirow{6}{*}{ Zone 4} & Mean & 28.018 & 6.461 & 1.971 & 0.692 & 0.853 & 37.996 & Low risk \\
\hline & SD & 10.113 & 2.115 & 0.680 & 0.140 & 0.268 & 11.521 & \\
\hline & General mean & 62.224 & 8.452 & 6.452 & 0.696 & 1.083 & 78.907 & Low risk \\
\hline & SD & 32.093 & 2.110 & 3.871 & 0.184 & 0.302 & 36.584 & \\
\hline & Minimum & 15.587 & 3.690 & 1.168 & 0.391 & 0.515 & 24.316 & \\
\hline & Maximum & 133.240 & 12.600 & 14.898 & 1.108 & 1.669 & 155.669 & \\
\hline
\end{tabular}

sampling sites presented a low potential ecological risk $(\mathrm{RI}<95)$ and the remaining $34.6 \%$ were classified as moderate risk $(95 \leq \mathrm{RI}<190)$, this could be attributed to the toxicity of heavy metals released by the anthropic activities such as agricultural practices ( $\mathrm{As}, \mathrm{Cd}$ and $\mathrm{Pb}$ ) and natural sources. Moderate risk was obtained for $100 \%, 33.3 \%$ and $16.7 \%$ of the sampled sites, and these values correspond to the towns of Huancayo, Jauja and Chupaca respectively. The metalloid As was the main contributor to the total ecological risk with a contribution of $61.5 \%$, consequently it is the main toxic element in soils followed for $\mathrm{Cd}$ and $\mathrm{Pb}$, which could represent a potential ecological risk for the high Andean ecosystem. These results that coincide with those reported by Xiao et al. (2019), so it is likely that the most predominant contribution of heavy metals to agricultural soils is the application of chemical fertilizers, organic fertilizers and pesticides (Mirzaei et al. 2019). Continuous monitoring of the use of agrochemicals in the Andean products crops is suggested in order to reduce the possible ecological risks caused by As and heavy metals in the high Andean soils of the Junín region.

\section{Identification of sources of heavy metals in high Andean soils}

According to Pearson's correlation coefficients for metals and arsenic in the soil samples, relatively strong and highly significant correlations $(\mathrm{p}<0.01)$ were found between As-Cd and As- $\mathrm{Pb}(0.504$ and 0.663$)$, which could indicate sources common contamination levels for all three metals. Likewise, the positive and significant correlations were observed for $\mathrm{Cd}-\mathrm{Pb}(0.527)$ and $\mathrm{Pb}-\mathrm{Zn}(0.728)$ and would reveal a common origin for these elements that probably occur as a result of the contributions from the anthropogenic activities (Y. Wang et al.2020). Correlation $(\mathrm{p}<0.05)$ was also observed between As-Zn (0.486). The concentrations of all metals were positively correlated with each other. This suggests that these elements have the same source of contamination, except the Fe content that did not show a significant correlation with the other metals, indicating that the sources of $\mathrm{Fe}$ accumulation come from other sources.

Principal Component Analysis (PCA) identifies the sources responsible for the heavy metal variations in soils (Zhang et al. 2018). Bartlett's

Table 4. Total variance explained and component matrix for heavy metals in soils

\begin{tabular}{|c|c|c|c|c|c|c|}
\hline \multirow{2}{*}{ Component } & \multicolumn{3}{|c|}{ Initial eigenvalues } & \multirow{2}{*}{ Element } & \multicolumn{2}{|c|}{ Component matrix } \\
\hline & Total & $\%$ of variance & Cumulative $\%$ & & PCA1 & PCA2 \\
\hline 1 & 2.650 & 52.998 & 52.998 & As & 0.829 & -0.068 \\
\hline 2 & 0.950 & 19.001 & 72.000 & $\mathrm{Cd}$ & 0.668 & 0.237 \\
\hline 3 & 0.817 & 16.336 & 88.336 & $\mathrm{~Pb}$ & 0.916 & -0.168 \\
\hline 4 & 0.405 & 8.109 & 96.445 & $\mathrm{Fe}$ & 0.335 & 0.871 \\
\hline 5 & 0.178 & 3.555 & 100.000 & $\mathrm{Zn}$ & 0.752 & -0.320 \\
\hline
\end{tabular}


analysis $(\mathrm{p}<0.01)$ revealed that the original data are adequate for PCA. According to the eigenvalue $>0.95$, two main components for heavy metals in soils were extracted, and the contribution rate of the accumulated variance was $72 \%$ (Table 4 ). The elements $\mathrm{As}, \mathrm{Cd}, \mathrm{Pb}$ and $\mathrm{Zn}$ had higher loads in the first principal component (PCA1) with a contribution rate of $53 \%$ of the total variance with relatively strong associations between the four metals, this could indicate that the heavy metal contamination of soils mainly originates from the human activities such as agricultural practices, the repeated and prolonged application of animal manure (sheep, cattle and poultry) causes the incorporation of $\mathrm{As}, \mathrm{Cd}, \mathrm{Pb}$ and $\mathrm{Zn}$ in soils, as reported from the previous studies in China (Liu et al. 2020, Yang et al. 2017, Zhang et al. 2012). In addition, the accumulation of As and Cd could also be attributed to the use of inorganic fertilizers, especially phosphate fertilizers, and the use of agrochemicals such as pesticides that can be the main source of contribution of As in agricultural soils (Solgi et al. 2018, L. Wang et al. 2019, S. Wang et al. 2019). As in surface soils exceeds the background value six times, which could indicate that the farmers in the four study areas would be using pesticides for pest and disease control of their Andean crops. On the other hand, the proximity to the urban area could increase the content of $\mathrm{Pb}$ in the soil due to the gas emissions from transport vehicles (Cai et al. 2019) especially in zones 2 and 3, as well as the transport of atmospheric particles for the wind product of the emission of toxic gases from the $\mathrm{Pb}$ smelter of the $\mathrm{La}$ Oroya Metallurgical Complex the operation of which began in 1928, possibly causing the deposition of $\mathrm{Pb}$ in the upper layer of the soil.

The second main component (PCA2) was composed with maximum loads in $\mathrm{Fe}$ and was explained with $19.0 \%$ of the total variance, which suggests that the distribution of Fe could be controlled mainly for the parental material of the soil. This factor was considered as a natural source of heavy metals from the topsoil that does not exceed the background value. These results are consistent with the studies of Jiang et al. (2020) and Li et al. (2020). The study provides valuable information on the risks of contamination for As and heavy metals in soils of high Andean ecosystems.

\section{CONCLUSIONS}

The concentration of heavy metals and arsenic in the high Andean soils were found below the national and international environmental quality standards for soils. However, $\mathrm{As}, \mathrm{Pb}$ and $\mathrm{Zn}$ registered higher concentrations than the background values; $61.5 \%$ of the sampling sites presented a moderate contamination degree. As showed the greatest contribution to the contamination degree of soil in the high Andean areas of Huancayo and Jauja. According to the values of the geoaccumulation index (Igeo), As presented the highest load of accumulated pollutants in soils by anthropogenic contribution. The potential ecological risk (RI) of the high Andean soils in the four studied zones ranged from low to moderate, As was the main contributor to the total ecological risk, and the Huancayo zone presented the highest potential ecological risk classified as moderate. The presence of $\mathrm{As}, \mathrm{Pb}$ and $\mathrm{Zn}$ in the surface soils was attributed to the use of organic and inorganic fertilizers and pesticides in the Andean products crops. Considering the level of contamination and the potential for ecological risk of soils by heavy metals, it is necessary to analyze and verify the effects of the use of animal manure and inorganic fertilizers on the accumulation of heavy metals in soils and Andean agricultural products to protect the health of local residents and the environment.

\section{Acknowledgment}

The authors thank the National University of the Center of Peru for the support in the execution of this study, as well as the peasants of the high Andean areas for the information and authorization in the taking of samples.

\section{REFERENCES}

1. Alloway B. 2013. Heavy metals in soils. Trace metals and metalloids in soils and their bioavailability. Springer, New York London

2. Baran A., Wieczorek J., Mazurek R., Urbański K., Klimkowicz-Pawlas A. 2018. Potential ecological risk assessment and predicting zinc accumulation in soils. Environmental Geochemistry and Health, 40(1), 435-450.

3. Bhatti SS., Bhat SA., Kumar V., Kaur M., Minakshi, Sambyal V., ... Nagpal A. K. 2018. Ecological risk assessment of metals in roadside agricultural soils: A modified approach. Human and Ecological Risk 
Assessment, 24(1), 186-201.

4. Bhatti SS., Kumar V., Kumar A., Gouzos J., Kirby J., Singh J., ... Nagpal AK. 2018. Potential ecological risks of metal(loid)s in riverine floodplain soils. Ecotoxicology and Environmental Safety, 164, 722-731.

5. Cai LM., Wang QS., Wen HH., Luo J., Wang S. 2019. Heavy metals in agricultural soils from a typical township in Guangdong Province, China: Occurrences and spatial distribution. Ecotoxicology and Environmental Safety, 168, 184-191.

6. Cai LM., Xu ZC., Qi JY., Feng ZZ., Xiang TS. 2015. Assessment of exposure to heavy metals and health risks among residents near Tonglushan mine in $\mathrm{Hu}-$ bei, China. Chemosphere, 127, 127-135.

7. CEPA. 1995. Environmental quality standards for soils (GB15618-1995), Chinese Chinese Environmental Protection Administration.

8. Chandrasekaran A., Ravisankar R. 2019. Potential ecological risk assessment in soils of Yelagiri hill, Tamil Nadu using energy dispersive X-ray fluorescence (EDXRF) technique. Applied Radiation and Isotopes, 147, 76-82.

9. Chang Kee J., Gonzales MJ., Ponce O., Ramírez L., León V., Torres A., ... Loayza-Muro R. 2018. Accumulation of heavy metals in native Andean plants: potential tools for soil phytoremediation in Ancash (Peru). Environmental Science and Pollution Research, 25(34), 33957-33966.

10. Chen H., Teng Y., Lu S., Wang Y., Wang J. 2015. Contamination features and health risk of soil heavy metals in China. Science of the Total Environment, 512-513, 143-153.

11. Davies BE. 1987. Consequences of environmental contamination by lead mining in Wales. Hydrobiologia, 149(1), 213-220.

12. Del Aguila Lopez SG. 2018. El cultivo e importancia socio-económico-cultural del cultivo de la mashua. Universidad Nacional de Educación.

13. Enuneku A., Biose E., Ezemonye L. 2017. Levels, distribution, characterization and ecological risk assessment of heavy metals in road side soils and earthworms from urban high traffic areas in Benin metropolis, Southern Nigeria. Journal of Environmental Chemical Engineering, 5(3), 2773-2781.

14. Essien JP., Inam ED., Ikpe DI., Udofia GE., Benson NU. 2019. Ecotoxicological status and risk assessment of heavy metals in municipal solid wastes dumpsite impacted soil in Nigeria. Environmental Nanotechnology, Monitoring and Management, 11.

15. Ghanavati N., Nazarpour A., De Vivo B. 2019. Ecological and human health risk assessment of toxic metals in street dusts and surface soils in Ahvaz, Iran. Environmental Geochemistry and Health, 41(2), 875-891.
16. Hakanson L. 1980. An ecological risk index for aquatic pollution control. A sedimentological approach. Water Research, 14(8), 975-1001.

17. Huang J., Peng S., Mao X., Li F., Guo S., Shi L., ... Zeng G. 2019. Source apportionment and spatial and quantitative ecological risk assessment of heavy metals in soils from a typical Chinese agricultural county. Process Safety and Environmental Protection, 126, 339-347.

18. Huang SS., Liao QL., Hua M., Wu XM., Bi KS., Yan CY., ... Zhang XY. 2007. Survey of heavy metal pollution and assessment of agricultural soil in Yangzhong district, Jiangsu Province, China. Chemosphere, 67(11), 2148-2155.

19. Islam MS., Ahmed MK., Habibullah-Al-Mamun M., Eaton DW. 2017. Human and ecological risks of metals in soils under different land use in an urban environment of Bangladesh. Pedosphere.

20. Jiang HH., Cai LM., Wen HH., Hu GC., Chen LG., Luo J. 2019. An integrated approach to quantifying ecological and human health risks from different sources of soil heavy metals. Science of the Total Environment, 701, 134466.

21. Kabata-Pendias A. 2011. Trace elements in soils and plant. Taylor and Francis Group, New York,

22. Kabata-Pendias, A., Mukherjee AB. 2007. Trace elements from soil to human. Springer Berlin Heidelberg, New York.

23. Kamani H., Mahvi AH., Seyedsalehi M., Jaafari J., Hoseini,M., Safari GH., ... Ashrafi SD. 2017. Contamination and ecological risk assessment of heavy metals in street dust of Tehran, Iran. International Journal of Environmental Science and Technology, 14(12), 2675-2682.

24. Kicińska A. 2020. Lead and zinc in soils around a zinc-works - presence, mobility and environmental risk. Journal of Ecological Engineering, 21(4), 185-198.

25. Kumar V., Sharma A., Kaur P., Singh Sidhu GP., Bali AS., Bhardwaj R., ... Cerda A. 2019. Pollution assessment of heavy metals in soils of India and ecological risk assessment: A state-of-the-art. Chemosphere, 216, 449-462.

26. Li J., Wang G., Liu F., Cui L., Jiao Y. 2020. Source apportionment and ecological-health risks assessment of heavy metals in topsoil near a factory, Central China. Exposure and Health

27. Li L., Wu J., Lu J., Min X., Xu J., Yang L. 2018. Distribution, pollution, bioaccumulation, and ecological risks of trace elements in soils of the northeastern Qinghai-Tibet Plateau. Ecotoxicology and Environmental Safety, 166, 345-353.

28. Liang Q., Xue Z., Wang F. 2015. Contamination and health risks from heavy metals in cultivated soil in Zhangjiakou City of Hebei Province, 
China. Environmental Monitoring and Assessment, 187(12), 754.

29. Liu M., Han Z., Yang Y. 2019. Accumulation, temporal variation, source apportionment and risk assessment of heavy metals in agricultural soils from the middle reaches of Fenhe River basin, North China. RSC Advances, 9(38), 21893-21902.

30. Liu WR., Zeng D., She L., Su WX., He DC., Wu GY., ... Ying GG. 2020. Comparisons of pollution characteristics, emission situations and mass loads for heavy metals in the manures of different livestock and poultry in China. Science of The Total Environment, 734, 139023.

31. Loayza-Muro R. 2016. Environmental damages from mining in Peru: What to do with it? Goals from Peru to the bicentennial [in spanish].

32. Mamut A., Eziz M., Mohammad A. 2018. Pollution and ecological risk assessment of heavy metals in farmland soils in Yanqi County, Xinjiang, Northwest China. Eurasian Soil Science, 51(8), 985-993.

33. Ministry of the Environment (MINAM). 2017. Approve environmental quality standards for soil. D. S. N ${ }^{\circ}$ 011-2017-MINAM., (E1 Peruano), December 2, 2017 [in spanish].

34. Mirzaei Aminiyan M., Baalousha M., Mousavi R., Mirzaei Aminiyan F., Hosseini H., Heydariyan A. 2018. The ecological risk, source identification and pollution assessment of heavy metals in road dust: A case study in Rafsanjan, SE Iran. Environmental Science and Pollution Research, 25(14), 13382-13395.

35. Mirzaei M., Marofi S., Solgi E., Abbasi M., Karimi R., Riyahi Bakhtyari HR. 2019. Ecological and health risks of soil and grape heavy metals in long-term fertilized vineyards (Chaharmahal and Bakhtiari province of Iran). Environmental Geochemistry and Health, 42, 27-43.

36. Muller G. 1969. Index of geoaccumulation in sediments of the Rhine River. GeoJournal, 2, 108-118.

37. Muller G. (1979). Heavy metals in the sediment of the Rhine-changes seity. Umschau in Wissenschaft Und Technik, 79, 778-783.

38. Rai PK., Lee SS., Zhang M., Tsang YF., Kim KH. 2019. Heavy metals in food crops: Health risks, fate, mechanisms, and management. Environment International, 125, 365-385.

39. Rehman I. ur, Ishaq M., Ali L., Khan S., Ahmad I., Din IU., Ullah H. 2018. Enrichment, spatial distribution of potential ecological and human health risk assessment via toxic metals in soil and surface water ingestion in the vicinity of Sewakht mines, district Chitral, Northern Pakistan. Ecotoxicology and Environmental Safety, 154, 127-136.

40. Rehman U. ur, Khan S., Muhammad S. 2018. Associations of potentially toxic elements (PTEs) in drinking water and human biomarkers: a case study from five districts of Pakistan. Environmental Science and Pollution Research, 25(28), 27912-27923.

41. Shen Z., Xu D., Li L., Wang J., Shi X. 2019. Ecological and health risks of heavy metal on farmland soils of mining areas around Tongling City, Anhui, China. Environmental Science and Pollution Research, 26(15), 15698-15709.

42. Solgi E., Sheikhzadeh H., Solgi M. 2018. Role of irrigation water, inorganic and organic fertilizers in soil and crop contamination by potentially hazardous elements in intensive farming systems: Case study from Moghan agro-industry, Iran. Journal of Geochemical Exploration, 185, 74-80.

43. Taylor SR., Mclennan SM. 1995. The geochemical the continental evolution crust. American Geophysical Union, 33(2), 241-265.

44. Tomlinson DL., Wilson JG., Harris CR., Jeffrey DW. 1980. Problems in the assessment of heavymetal levels in estuaries and the formation of a pollution index. Helgoländer Meeresuntersuchungen, 33(1-4), 566-575.

45. Wang L., Gao S., Yin X., Yu X., Luan L. 2019. Arsenic accumulation, distribution and source analysis of rice in a typical growing area in north China. Ecotoxicology and Environmental Safety, 167(April 2018), 429-434.

46. Wang S., Cai LM., Wen HH., Luo J., Wang QS., Liu X. 2019. Spatial distribution and source apportionment of heavy metals in soil from a typical countylevel city of Guangdong Province, China. Science of the Total Environment, 655, 92-101.

47. Wang Y., Duan X., Wang L. 2020. Spatial distribution and source analysis of heavy metals in soils influenced by industrial enterprise distribution: Case study in Jiangsu Province. Science of the Total Environment, 710, 134953.

48. Weissmannová HD., Pavlovský J. 2017. Indices of soil contamination by heavy metals - methodology of calculation for pollution assessment (minireview). Environmental Monitoring and Assessment, 189(12), 616-641.

49. Wu J., Lu J., Li L., Min X., Luo Y. 2018. Pollution, ecological-health risks, and sources of heavy metals in soil of the northeastern Qinghai-Tibet Plateau. Chemosphere, 201, 234-242.

50. Wu Q., Leung JYS., Geng X., Chen S., Huang X., Li H., ... Lu Y. 2015. Heavy metal contamination of soil and water in the vicinity of an abandoned ewaste recycling site: Implications for dissemination of heavy metals. Science of the Total Environment, 506-507, 217-225.

51. Xiao R., Guo D., Ali A., Mi S., Liu T., Ren C., ... Zhang Z. 2019. Accumulation, ecologicalhealth risks assessment, and source apportionment of heavy metals in paddy soils: A case study in 
Hanzhong, Shaanxi, China. Environmental Pollution, 248, 349-357.

52. Yang Q., Li Z., Lu X., Duan Q., Huang L., Bi J. 2018. A review of soil heavy metal pollution from industrial and agricultural regions in China: Pollution and risk assessment. Science of the Total Environment, 642, 690-700.

53. Yang Xiaolong, Yuan X., Zhang A., Mao Y., Li Q., Zong H., ... Li X. 2015) Spatial distribution and sources of heavy metals and petroleum hydrocarbon in the sand flats of Shuangtaizi Estuary, Bohai Sea of China. Marine Pollution Bulletin, 95(1), 503-512.

54. Yang Xinping, Li Q., Tang Z., Zhang W., Yu G., Shen Q., Zhao FJ. 2017. Heavy metal concentrations and arsenic speciation in animal manure composts in China. Waste Management, 64, 333-339.
55. Zhang F., Li Y., Yang M., Li W. 2012. Content of heavy metals in animal feeds and manures from farms of different scales in northeast China. International Journal of Environmental Research and Public Health, 9(8), 2658-2668.

56. Zhang P., Qin C., Hong X., Kang G., Qin M., Yang D., ... Dick RP. 2018. Risk assessment and source analysis of soil heavy metal pollution from lower reaches of Yellow River irrigation in China. Science of the Total Environment, 633, 1136-1147.

57. Zhu D., Wei Y., Zhao Y., Wang Q., Han J. 2018. Heavy metal pollution and ecological risk assessment of the agriculture soil in Xunyang mining area, Shaanxi Province, Northwestern China. Bulletin of Environmental Contamination and Toxicology, 101(2), 178-184. 